\title{
Growth and yield performances of rice (Oryza sativa var. nerica) after exposure to biosynthesized nanoparticles
}

\author{
B. Ikhajiagbe ${ }^{1}$, F. A. Igiebor ${ }^{1,2}$ and M. C. Ogwu ${ }^{1,3^{*}}$ (D)
}

\begin{abstract}
Background: Rice (Oryza sativa L.) is a common staple food in Nigeria. However, cultivation is impaired by heavy metal contamination, particularly iron (Fe). This study aimed to investigate the impacts of biosynthesized nanoparticles (NPs) in enhancing the growth and yield components of rice sown in ferruginous soil. Viable seeds of $O$. sativa var. nerica were sown in ferruginous and non-ferruginous soils. After four weeks, the plants were exposed to foliar sprays of biosynthesized NPs from silver nitrate, using extracts of leaves of Carica papaya, Vernonia amygdalina, Moringa oleifera, and Azadirachta indica; and the flowers of Hibiscus sabderiffa, following standard procedure. The originally prepared stock solution was diluted to give 5, 15, and 30\% concentrations of each synthesized NP.

Results: Results showed that soil ferrugenicity impeded the growth and yield of rice. Azadirachta-synthesized NPs was better enhanced in the ferruginous soils, which might be due to Fe interaction and activities. Moreover, there was increased antioxidant activity in the ferruginous rice compared to the non-ferruginous rice, thus it is evidence that ferrugenicity is a major source of physiological stress for the rice plant.
\end{abstract}

Conclusion: The study provided evidence that Ag-NPs can enhance plant yield by huge proportions in ferruginous soil, a condition (ferrugenicity) that was hitherto inimical to yield disposition of rice.

Keywords: Nanoparticles, Oryza sativa, Ferruginous soil, Seeds, Plant growth, Crop yield

\section{Background}

In the pursuit of food security, the emphasis among others has been on the need to set up sustainable farms. However, crop productivity may be significantly affected by such environmental problems as soil metal levels aggravated either by anthropogenic activities or natural causes (Osawaru et al. 2013a, b; Ikhajiagbe and Ogwu 2020). Rice (Oryza sativa, Poaceae) is one of the leading food crops for over half of the world's population (FAO 2003). It is a major source of carbohydrate, vitamins and minerals which provides energy for the body. Bruinsma (2003) posited that rice is the foremost source of calories,

\footnotetext{
${ }^{*}$ Correspondence: matthew.ogwu@uniben.edu

${ }^{1}$ Department of Plant Biology and Biotechnology, Faculty of Life Sciences,

University of Benin, PMB 1154, Benin, Edo, Nigeria

Full list of author information is available at the end of the article
}

whereas FAO (2001) estimated that per annum rice production would need to increase beyond 586 million metric tons to meet the proposed global demand of about 756 million metric tons by the year 2030. In Nigeria, it is valued as the most consumed staple food and a major cash crop. Nigerian per capita consumption has risen immensely and was estimated at 10 per cent per annum as a result of changes in consumer choices (Akande 2003). Also, inadequate domestic production had to be complemented with massive importation and value at different times (Saka and Lawal 2009).

Studies have shown that occasionally when food agencies donate food to internally displaced persons, people in need of rice is predominantly top of the list, thus the importance of rice cultivation in Nigeria. Currently, the Nigerian government is trying to ensure self-sustainability in rice production by closing land borders where rice 
(and other items) are often illegally smuggled into the country and enforcing acquisition of locally grown rice, which has led to a drastic reduction in annual imports. Owing to this decree, Kebbi state has gained a reputation as a champion of the rice revolution in Nigeria and the recent declaration by the state government of a 150 billion naira profit from the rice effort in 2017 (Bivbere 2018). USAID (2010) reported that in West Africa, Nigeria, is the major rice importer, with an average annual importation of 1.6 million metric tons since the year 2000. Nigeria produces only about 2.8 million metric tons with a shortage of 1.6 million metric tons. Rice consumption in Nigeria is expected to continue growing into the future because of the country's high population growth rate, fast urbanization and unsatisfactory domestic production. Faced with the threat of shortages in the supply of rice, there is a need to increase domestic production of Rice to contribute to food security in Nigeria. If there is increased local production of rice for domestic consumption and export, the country is sure to earn more than enough foreign exchange to pursue sustainable economic development (Ogwu 2019a, b; Osawaru and Ogwu 2020). The adoption of technologies and improved management practices should lead to a significant yield increase in rice production (Nwite et al. 2010).

Recently, studies have shown that nanoparticles are synthesized to enhance crop development. Nanoparticles are particulate material with at least one dimension of less than $100 \mathrm{~nm}$. Silver nanoparticles (Ag-NP) are a very important and frequently used tool in nanotechnology, owing to the unique biological, physical and chemical properties. The efficiency of Ag-NPs is determined by their size, chemical composition, reactivity, surface covering and the dose at which they are effective (Khodakovskaya et al. 2012). Currently, these Ag-NPs have invoked much interest and are applied in various sectors including biomedical catalysis, optical, electronic and agricultural field. Also, studies have shown that nanoparticles improve plant structural development (Ngo et al. 2014). Plant-based synthesis of nanomaterials is gaining significant interest owing to the use of mild experimental conditions of $\mathrm{pH}$, temperature and pressure. To prolong the life span of these nanoparticles, stabilizing agents and pathways that are non-toxic, and environmentally friendly are now employed. The sensitivity and responses towards these nanoparticles vary considerably among plant species and growing conditions.

The present study aims to demonstrate the effects of Ag-NPs synthesized from Azadirachta indica (Meliaceae), Carica papaya (Caricaceae), Moringa oleifera (Moringaceae), Vernonia amygdalina (Asteraceae), and Hybridus sabdariffa (Malvaceae), in Rice (O. sativa). The plant growth parameters (leaf surface area, shoot and root lengths, leaf number, sheath length, internode, number and length of ligule) were investigated.

\section{Methods \\ Description of the study area}

The experiment was conducted at the Department of Plant Biology and Biotechnology Botanic Garden. The site was predominated by annual weeds and grasses before it was cleared for use. A list of these weed species and their diversity patterns in the study area can be found in Osawaru et al. (2014) while the climatic and environmental conditions are fully described in Osawaru and Ogwu (2013) and Ogwu et al. (2016).

\section{Collection of plant samples}

Leaves of four plant species (Carica papaya, Vernonia amygdalina, Moringa oleifera, and Azadiracta indica) and the flowers of Hibiscus sabdariffa were used in the study. They were collected from healthy matured plant stands within the study area.

\section{Preparation of plant leaf/flower extracts}

The samples were washed with de-ionized water and were then crushed in sterile de-ionized water, boiled and filtered through ethanol and then centrifuged following the methods of Anandalakshi and Venugobal (2017).

\section{Rice variety used}

Rice variety used was Nerica was obtained from Raymos Guanah Farms Limited, Delta State, Nigeria.

\section{Soil collection and sowing}

Ferruginous soil was collected from reddish soil portion at the Botanic Garden, Department of Plant Biology and Biotechnology (Ikhajiagbe et al. (2021), whereas nonferruginous soil was collected from mulched garden soil at Faculty of Agriculture, University of Benin. Rice seeds were sown at the rate of twenty seeds and thinned down to five stands after two weeks.

\section{Maintaining soil moisture}

The set up was in the open (no shade) and as such relied basically on rainfall. However, the soil moisture was always maintained following the methods of USDA (2010).

\section{Synthesis of silver nanoparticles (Ag-NPs)}

Ten millilitres of $1 \mathrm{mM}$ aqueous solution of silver nitrate $\left(\mathrm{AgNO}_{3}\right)$ was used in the synthesis of NP using the prepared leaf extract solution and strictly following methods of Anandalakshi and Venugobal (2017). A colour change from light yellow to the dark brown colour indicated the formation of Ag-NPs. Thereafter, absorbance spectra of 
colloidal samples were taken in the range of $200-800 \mathrm{~nm}$ using a UV-VIS Spectrophotometer at $800 \mathrm{~nm}$ with distilled water as a reference. The absorbance spectra were compared with literature to confirm the formation of NP.

\section{Application of synthesized Ag-NPs}

Four weeks after sowing the rice, Ag-NPs synthesized in the laboratory within that same day were applied to the rice stands by foliar spray. A booster dose was applied two weeks later.

\section{Growth and yield parameters}

Plant height, leaf length, number of leaves, leaf area, the average length of the main root, number of primary root branches, stem girth, plant dry weight and number of tillers were observed. Harvest time, spikelet, grain length and diameter, shelling, the weight of panicle and foliar necrosis were assessed as part of the yield characteristics. Data were collected from samples at 12 and 17 weeks.

\section{Soil physiochemical parameter}

$\mathrm{pH}$, Electric conductivity, Total organic carbon, Total Nitrogen, Exchangeable acidity, Clay, Silt, Sand and Fe were determined in the laboratory according to the methods of APHA (2008).

\section{Biochemical characteristics}

Chlorophyll $a$, chlorophyll $b$, lycopene, and terpenoid of fresh leaves were determined according to the method of Moran (1982).

\section{Statistical analysis}

Data obtained from the analysis were subjected to statistical analysis mainly; descriptive statistics, as well as association and inferential statistics. Analyses of variance were conducted on a single factor basis since the soil used in the experiment was homogenized and homogeneity of the entire plot was also assumed to evaluate the data obtained.

\section{Results}

\section{Soil physico-chemical properties}

The results presented in Additional file 1: Table 1 shows the physical and chemical properties of the ferruginous and non-ferruginous soils used in this study. The result showed that originally the non-ferruginous soil $\mathrm{pH}$ was $6.37 \pm 0.34$ with electric conductivity of $297.24 \mu \mathrm{s} / \mathrm{cm}$. However, the iron content is significantly lower than the ferruginous soil at $203.19 \pm 19.23 \mathrm{mg} / \mathrm{kg}$.

\section{Growth characteristics}

The effect of Ag-NPs on morphological parameters was measured in terms of leaf length, plant height, no of leaves, stem girth, no of tillers, no of roots, the width of flag leaf, length of flag leaf (Tables 1, 2, 3, 4). There was a significant increase in leaf length in AZ30\% $(75.0 \mathrm{~cm})$ compared to the control $(49.8 \mathrm{~cm})$. Similarly, plant height ranged from $31.0 \mathrm{~cm}$ in AZ5\% to $59 \mathrm{~cm}$ in AZ30\% compared to $40 \mathrm{~cm}$ of plant height in the control. The number of leaves significantly increased upon application of nanoparticles. In the control, for example, there were 8 leaves (control) during harvest; however, these number of leaves had increased to as much as 26 leaves in MO5\%, 25 leaves in VA15\% and 24 leaves in ZO30\%. There generally 3-6 additional tillers per plant in the Nano-intervened plant compared to 2 additional tillers in the control (Table 1). Table 2 shows a continuation of growth parameters obtained during 17 weeks after sowing (12 weeks after application of nanoparticles) in the rice stands sown in the ferruginous soil. There were significant differences in plant height in MO5\% $(81.84 \mathrm{~cm})$ compared to Control $(25.45 \mathrm{~cm})$. Stem width of VA5\%, MO15\% and ZO30\% were same $(3.20 \mathrm{~cm})$ compared to control $(1.5 \mathrm{~cm})$. The number of leaves was significantly higher in AZ30\% (28) than control (15). Generally, the number of tillers per plant ranged between 1 and 5 in the nano-intervened plant compared to control. However, there were no significant differences in the number of tillers and numbers of roots in the nano-intervened plant $(\mathrm{p}=0.001)$. The root depth in CA5\% $(63.00 \mathrm{~cm})$ was significantly different from control $(28.00 \mathrm{~cm})$ (Table 2).

Table 3 compares the growth parameters of rice plants exposed to nanoparticles and sown in ferruginous (F) and non-ferruginous $(\mathrm{N})$ soils at 12 weeks after sowing (8 weeks after nano-intervention), it was observed that there were no significant differences in ZO5\%, AZ15\%, CA15\%, ZO15\%, VA15\%, MO15\%, ZO30\% and the control in terms of plant height. Similarly, the leave length of CA5\%, ZO5\%, VA5\%, MO5\%, CA15\%, VA15\%, MO15\%, AZ30\%, CA30\%, ZO30, VA30\% and MO30\% were significantly the same with the control $(p=0.001)$. The number of leaves of CA5\%, VA5\%, MO5\%, CA $15 \%$, VA $15 \%$, AZ30\%, CA30\%, ZO30\%, VA30\% $(p=0.001)$ were significantly different from the control $(p=0.742)$. The leaf width of ZO5\%, CA15\% and VA30\% ( $p=0.001)$ were significantly different from the control $(p=0.735)$.

\section{Yield characteristics}

The mean number of days to panicle emergence is presented in Table 4. The result showed that AZ5\% did not affect yield parameter at all in non-ferruginous soil, implying that the concentration of the nanoparticles might be toxic to the plant, whereas in ferruginous soil, there was emergence of the panicle. However, there was no significant difference in the emergence of panicle in $\mathrm{ZO} 15 \%, \mathrm{CA} 30 \%, \mathrm{ZO} 30 \%$, VA30\% as well as in 


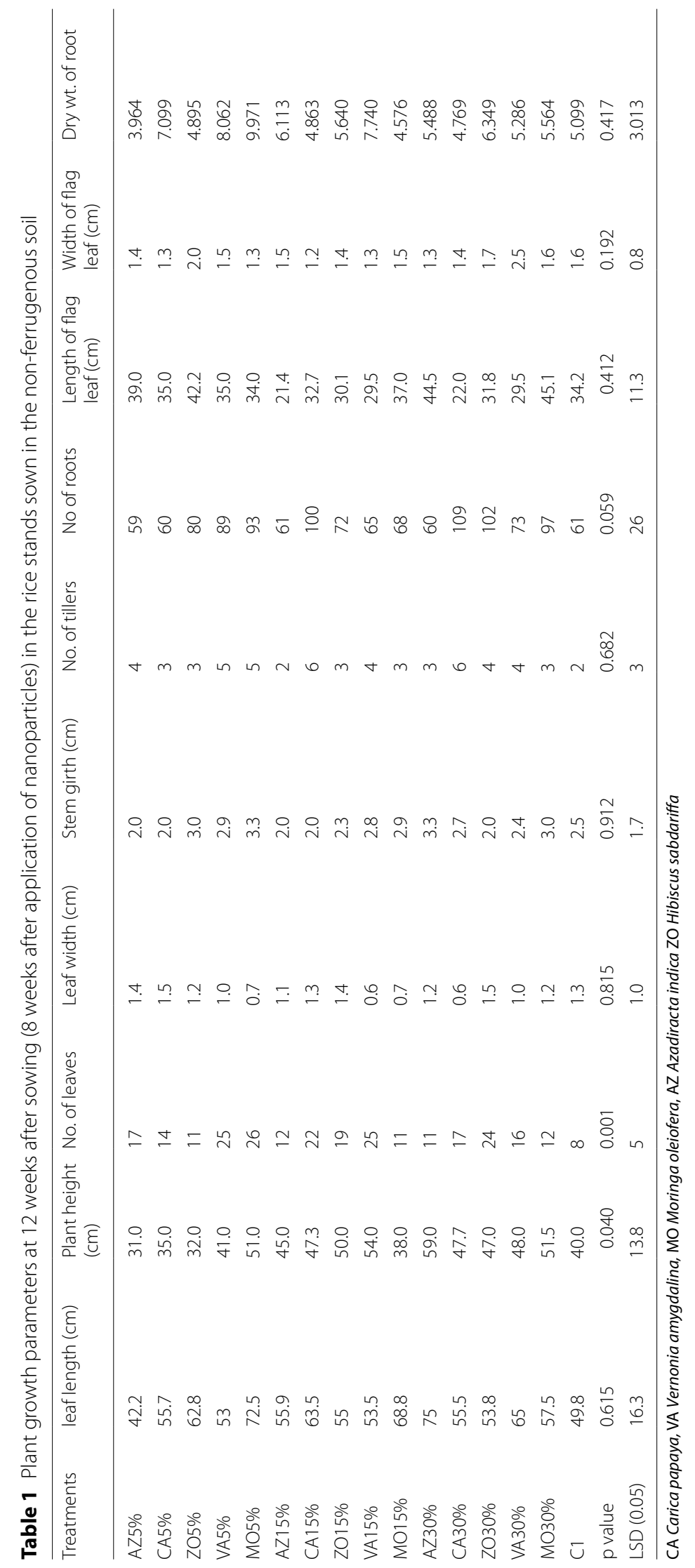


Table 2 The effects of nanoparticles on plant growth parameters at 17 weeks after sowing (12 weeks after application of nanoparticles) in ferruginous soil

\begin{tabular}{|c|c|c|c|c|c|c|c|c|}
\hline Treatment & $\begin{array}{l}\text { Plant } \\
\text { height } \\
(\mathrm{cm})\end{array}$ & Stem width $(\mathrm{cm})$ & No. of leaves & $\begin{array}{l}\text { Flag leaf } \\
\text { length }(\mathrm{cm})\end{array}$ & $\begin{array}{l}\text { Flag leaf } \\
\text { width }(\mathrm{cm})\end{array}$ & No. of tillers & No. of roots & Root depth $(\mathrm{cm})$ \\
\hline AZ5\% & 67.91 & 3.0 & 17 & 24.50 & 1.5 & 3 & 19 & 56.0 \\
\hline CA5\% & 69.86 & 3.0 & 10 & 36.50 & 1.4 & 2 & 20 & 63.0 \\
\hline ZO5\% & 81.34 & 2.7 & 7 & 24.10 & 1.4 & 2 & 37 & 61.0 \\
\hline VA15\% & 74.85 & 2.5 & 5 & 25.00 & 1.3 & 1 & 25 & 27.5 \\
\hline MO5\% & 81.84 & 3.0 & 18 & 19.00 & 1.5 & 3 & 26 & 32.0 \\
\hline AZ15\% & 62.87 & 2.6 & 15 & 24.50 & 1.5 & 3 & 19 & 33.0 \\
\hline CA15\% & 69.86 & 2.6 & 11 & 31.00 & 1.6 & 2 & 24 & 44.0 \\
\hline ZO15\% & 75.35 & 2.2 & 6 & 27.50 & 1.5 & 2 & 46 & 49.0 \\
\hline VA5\% & 34.93 & 3.2 & 20 & 21.00 & 1.3 & 4 & 10 & 37.0 \\
\hline MO15\% & 67.86 & 3.2 & 14 & 23.50 & 1 & 2 & 23 & 27.0 \\
\hline AZ30\% & 61.88 & 3.0 & 28 & 36.50 & 1.8 & 5 & 18 & 47.0 \\
\hline CA30\% & 48.9 & 2.7 & 13 & 35.00 & 1.4 & 3 & 15 & 46.5 \\
\hline ZO30\% & 58.88 & 3.2 & 22 & 22.00 & 1.1 & 5 & 26 & 40.0 \\
\hline VA30\% & 65.87 & 2.5 & 13 & 28.00 & 1.1 & 5 & 31 & 47.5 \\
\hline MO30\% & 55.89 & 3.1 & 12 & 25.00 & 0.8 & 2 & 28 & 17.5 \\
\hline Control & 25.45 & 1.5 & 15 & 21.87 & 0.8 & 3 & 7 & 28.0 \\
\hline$p$ value & 0.016 & 0.562 & $<0.001$ & 0.487 & 0.722 & $<0.001$ & $<0.001$ & 0.048 \\
\hline $\operatorname{LSD}(0.05)$ & 28.1 & 1.8 & 7 & 19.4 & & 2 & 14 & 23.9 \\
\hline
\end{tabular}

CA Carica papaya, VA Vernonia amygdalina, MO Moringa oleiofera, AZ Azadiracta indica ZO Hibiscus sabdariffa

Table 3 The effects of nanoparticles on growth parameters of rice plants exposed to nanoparticles and sown in ferruginous (F) and non-ferruginous $(\mathrm{N})$ soils at 12 weeks after sowing (8 weeks after nano-intervention)

\begin{tabular}{|c|c|c|c|c|c|c|c|c|c|c|c|c|}
\hline \multirow[t]{2}{*}{ Treatment } & \multicolumn{3}{|c|}{ Plant height (cm) } & \multicolumn{3}{|c|}{ Leave length (cm) } & \multicolumn{3}{|c|}{ No. of leaves } & \multicolumn{3}{|c|}{ Leaf width (cm) } \\
\hline & $\mathrm{F}$ & $\mathrm{N}$ & $p$ value & F & $\mathrm{N}$ & $p$ value & $\mathrm{F}$ & $\mathrm{N}$ & $p$ value & $\mathrm{F}$ & $N$ & $p$ value \\
\hline AZ5\% & 33.65 & 30.94 & 0.318 & 38.96 & 42.2 & 0.033 & 21 & 17 & 0.313 & 1.4 & 1.4 & 0.933 \\
\hline CA5\% & 37.92 & 34.93 & 0.137 & 23.98 & 55.7 & $<0.001$ & 8 & 14 & $<0.001$ & 0.8 & 1.5 & $<0.001$ \\
\hline ZO5\% & 71.86 & 31.94 & $<0.001$ & 35.96 & 62.8 & $<0.001$ & 15 & 11 & 0.138 & 1.1 & 1.2 & 0.632 \\
\hline VA5\% & 23.95 & 40.92 & 0.025 & 13.99 & 53 & $<0.001$ & 8 & 25 & $<0.001$ & 0.6 & 1.1 & 0.125 \\
\hline MO5\% & 55.89 & 50.9 & 0.552 & 31.97 & 72.5 & $<0.001$ & 10 & 26 & $<0.001$ & 1.2 & 0.7 & 0.092 \\
\hline AZ15\% & 38.92 & 44.91 & $<0.001$ & 42.96 & 55.9 & 0.031 & 9 & 12 & 0.522 & 1.3 & 1.1 & 0.144 \\
\hline CA15\% & 37.92 & 47.21 & $<0.001$ & 37.96 & 63.5 & $<0.001$ & 13 & 22 & $<0.001$ & 0.7 & 1.3 & $<0.001$ \\
\hline ZO15\% & 69.86 & 49.9 & $<0.001$ & 42.96 & 55 & 0.003 & 21 & 19 & 0.723 & 1.3 & 1.4 & 0.042 \\
\hline VA15\% & 23.95 & 53.89 & $<0.001$ & 20.98 & 53.5 & $<0.001$ & 7 & 25 & $<0.001$ & 0.5 & 0.6 & 0.152 \\
\hline MO15\% & 55.89 & 37.92 & $<0.001$ & 28.97 & 68.8 & $<0.001$ & 11 & 11 & 0.912 & 1.1 & 0.7 & 0.318 \\
\hline AZ30\% & 47.9 & 58.88 & 0.053 & 35.96 & 75 & $<0.001$ & 14 & 11 & $<0.001$ & 1.3 & 1.2 & 0.627 \\
\hline CA30\% & 19.96 & 47.6 & 0.032 & 12.99 & 55.5 & $<0.001$ & 6 & 17 & $<0.001$ & 0.4 & 0.6 & 0.061 \\
\hline ZO30\% & 41.92 & 46.91 & $<0.001$ & 34.97 & 53.8 & $<0.001$ & 10 & 24 & $<0.001$ & 1.1 & 1.5 & 0.139 \\
\hline VA30\% & 48.9 & 47.9 & 0.792 & 16.98 & 65 & $<0.001$ & 9 & 16 & $<0.001$ & 0.5 & 1.2 & $<0.001$ \\
\hline MO30\% & 46.41 & 51.4 & 0.418 & 30.97 & 57.5 & $<0.001$ & 13 & 12 & 0.772 & 1.1 & 1.2 & 0.639 \\
\hline Control & 48.9 & 39.92 & $<0.001$ & 28.13 & 49.8 & $<0.001$ & 10 & 8 & 0.742 & 1.3 & 1.4 & 0.735 \\
\hline
\end{tabular}

CA Carica papaya, VA Vernonia amygdalina, MO Moringa oleiofera, AZ Azadiracta indica ZO Hibiscus sabdariffa

the control of both soils. Table 5 shows the plant yield parameter at plant harvest at 12 weeks after sowing. The result showed that AZ5\% did not have significant effects on yield parameter, which might imply possible toxicity of nanoparticles concentration to the plant. There was a significant difference in the shelling per cent obtained 
upon the application of nanoparticles. As recorded, $61.45 \%$ shelling was obtained in the control compared to 83.83\% shelling in VA30\% and $84.22 \%$ shelling in AZ30\%. It is also important to note that, the highest percentage shelling was obtained in CA30\% with over 100\% shelling obtained compared to the control (Table 3). The weight of panicles in the study ranged from 0.08 to $2.281 \mathrm{~g}$. Similarly, the highest yield in terms of weight of rice grain was recorded in VA5\% (2.281 g) compared to the control which recorded $0.672 \mathrm{~g}$. Weight of rice grain in AZ15\%, CA15\%, VA15\%AZ30\%CA30\%, MO30\% were generally greater than $1 \mathrm{~g}$. Result of the study showed that there was no significant difference in the length of the grain $(1.4-1.6)$ and the diameter $(0.40-0.50 \mathrm{~cm})$ of the rice grains.

Table 6 shows the plant yield characteristics at 17 weeks after sowing in the ferruginous soils; $68.13 \%$ shelling was obtained in the control compared to $84.53 \%$ shelling in CA30\%, 82.41\% shelling in AZ5\%, 81.24\% shelling in AZ15\%, 81.23\% shelling in ZO5\% and 81.21\% shelling in VA5\%. The weight of panicles in the study ranged from 0.43 to $5.84 \mathrm{~g}$. The highest weight of panicle was recorded in AZ15\% (5.84 g) compared to the control $(1.41 \mathrm{~g})$. The highest yield in terms of weight of rice grain was recorded in AZ15\% (4.66 g) compared to the control which recorded $1.97 \mathrm{~g}$. Weight of rice grain per plant in ZO5\%, AZ15\%, CA15\%, MO15\%, AZ30\%, ZO30\%, VA30\% and $\mathrm{MO} 30 \%$ were generally greater than $1 \mathrm{~g}$. Table 7 shows the comparison of yield parameters of test plants under experimental conditions. It was observed that AZ15\% in the ferruginous soil recorded +366 yields while in non-ferruginous soil, it recorded +41.8 compared to the control where no yield was recorded. VA5\% in the non-ferruginous soil had +128 yields as against -5 yields in ferruginous soil. Generally, there was a significant difference in yields in ferruginous soils and the non-ferruginous soils. The occurrences of foliar necrosis during the study of the experimental conditions are presented in Table 8. Prominently necrosis appeared first like patches and then spread all over the plant until the entire leaf become necrotic. These were observed in $\mathrm{AZ} 5 \%, \mathrm{MO} 5 \%, \mathrm{MO} 15 \%$ and $\mathrm{AZ30 \%}$. In some other cases, necrosis began at the tip of the leaf and then later spread downwards until the entire leaf became necrotic in CA5\%, ZO5\%, VA5\%, AZ15\%, ZO15\%, VA15\%, CA30\%, $\mathrm{MO} 30 \%$ and the control in Ferruginous soils, whereas similar observation was seen in non-ferruginous soils. In MO15\% necrosis appeared first like burnt patches as well as a couple of brown patches and thereafter the entire leaf became necrotic in both ferruginous and non-ferruginous soils. Table 8 further shows modal necrotic time. In this case, the result presented the maximum time for a modal leaf to become entirely necrotic compared to

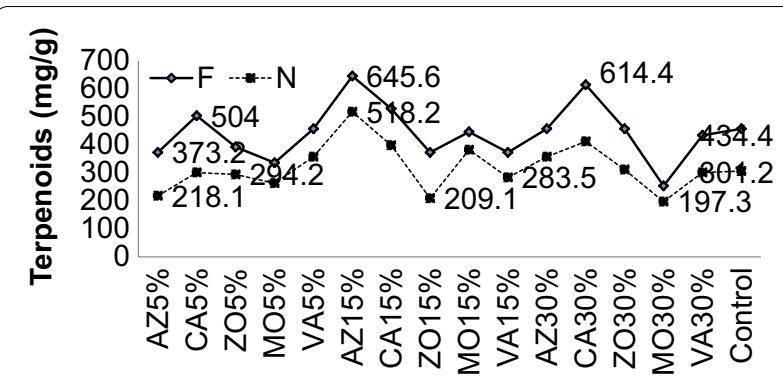

Fig. 1 Terpenoids activity in rice plants exposed to the experimental conditions. Keys: N plant innon-ferruginous soil, F plant inferruginous soil, CA Caricapapaya, VA Vernoniaamygdalina, MO Moringaoleifera, AZ Azadiractaindica ZO Hibiscus sabdariffa

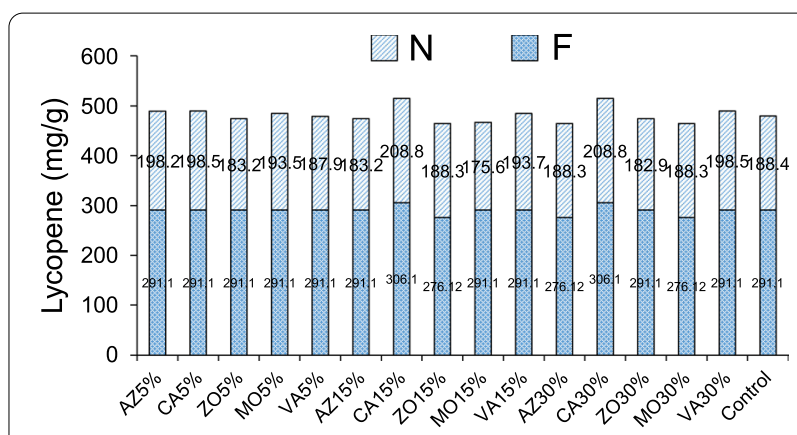

Fig. 2 Lycopene activity in rice plants exposed to the experimental conditions. Keys: $N$ plant innon-ferruginous soil, F plant inferruginous soil, CA Caricapapaya, VA Vernoniaamygdalina, MO Moringaoleifera, AZ Azadiractaindica ZO Hibiscus sabdariffa

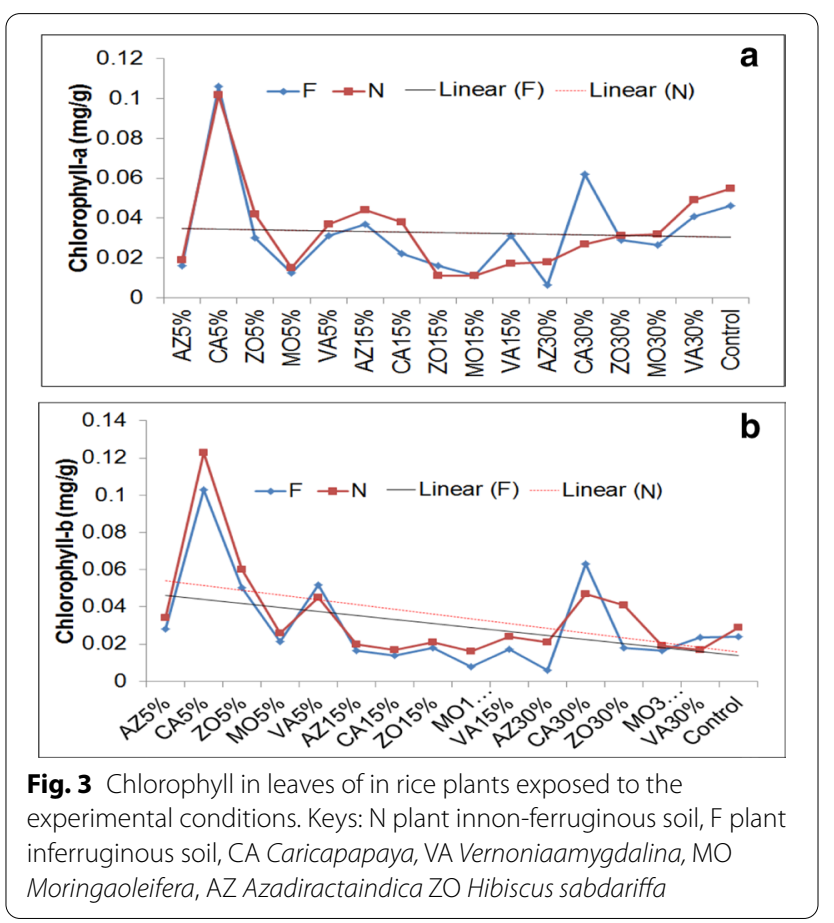




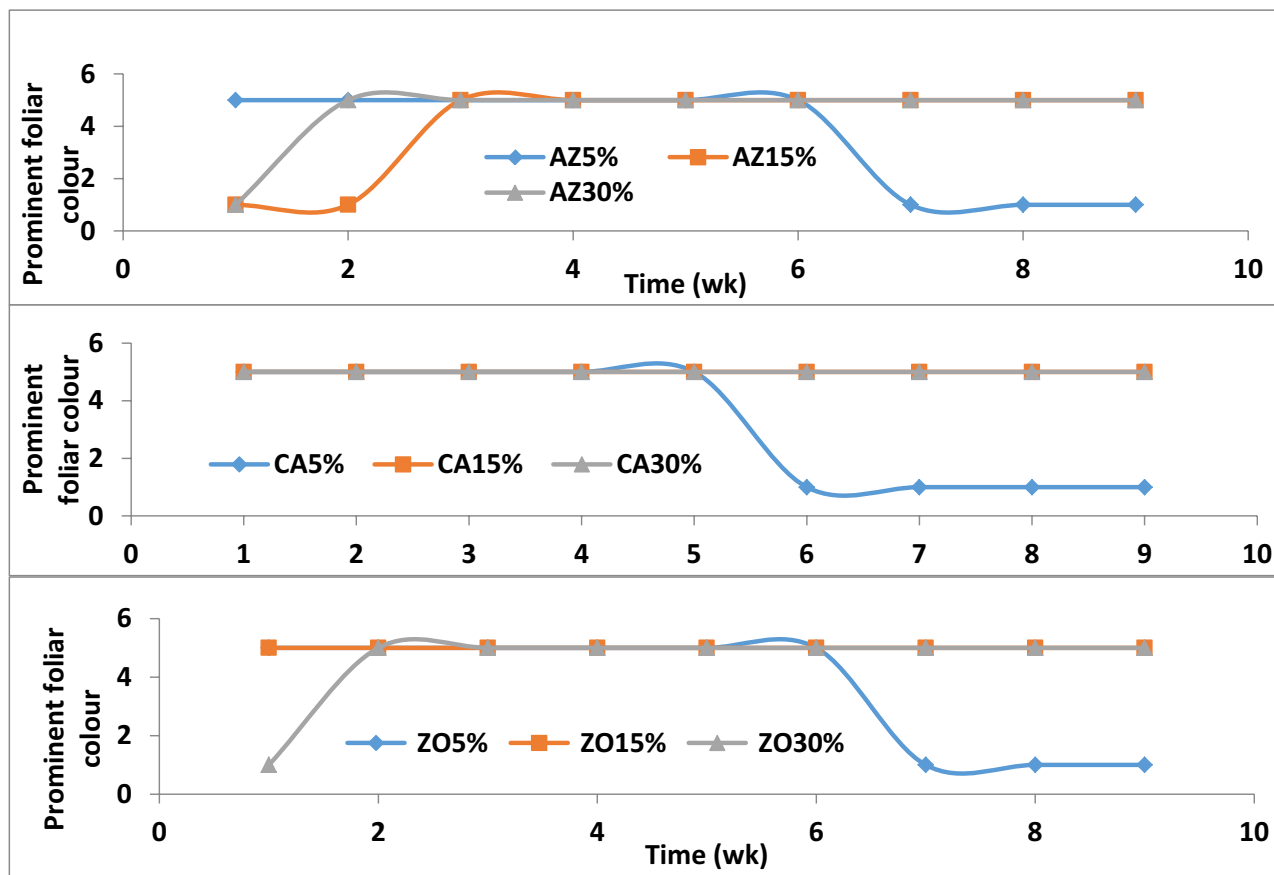

a
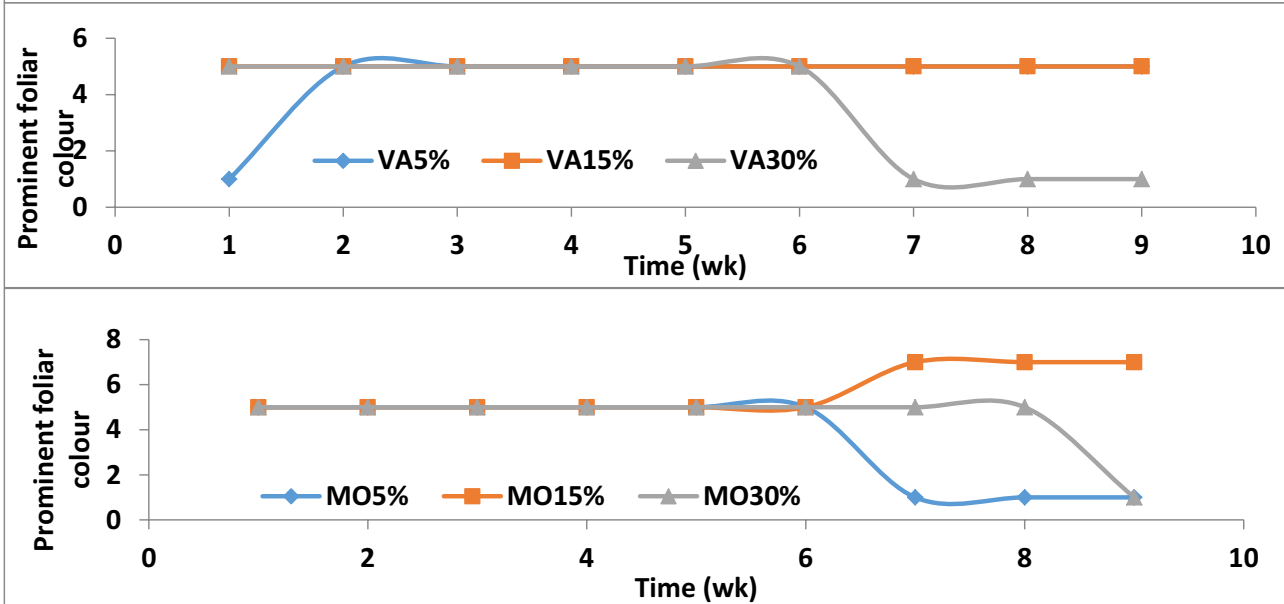

Fig. 4 Changes in foliar colouration during the study. Keys: The foliar colourationpresented are the most prominent leaf colour throughout the study. Colour code 1 is green-yellow, 2 lawn green, 3 dark sea green, 4 lime green, 5 olive drab,6 dark olive green, 7 green, 8 dark green

when the necrotic sign was first noticed (see also Additional file 1: Tables 2 and 3 ).

\section{Biochemical characteristics}

Results of terpenoids activity in rice plants exposed to the experimental condition are presented in Fig. 1. Plants sown in ferruginous soil had significantly higher terpenoid activity. The lycopene activity (Fig. 2) in rice plants exposed to various experimental conditions showed that lycopene in Ferruginous soils was generally high as compared to the control. The chlorophyll contents
(Fig. 3) of the leaves shows that there were changes in the chlorophyll pattern. In chlorophyll $a$, the trend lines superimpose on each other, that is, the patterns in both non-ferruginous and ferruginous soils were the same. In Fig. 4a prominently the leaves in AZ5\% during the first week was olive drab until the sixth week, but there was a drop in the shade of green to green-yellow colour, which might be an indication that the plants were becoming relatively chlorotic. In CA15\% the prominent foliar colour was olive drab between the first and the fifth week; however, upon application of nanoparticle, it maintained the olive drab colour but showed a relatively 


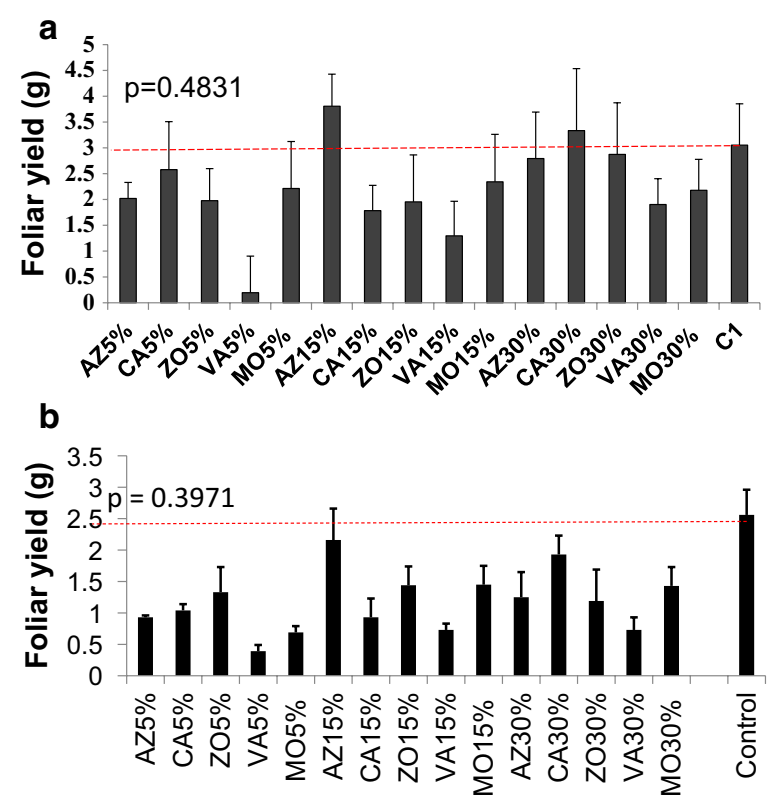

Fig. 5 a Foliar yield of N-rice plants at 12 weeks after sowing in non-ferruginous soil. Keys: N plant innon-ferruginous soil, F plant inferruginous soil, CA Caricapapaya, VA Vernoniaamygdalina, MO Moringaoleifera, AZ Azadiractaindica ZO Hibiscus sabdariffa. b Foliar yield of F-rice plants at 17 weeks after sowing in ferruginous soil. Keys: N plant innon-ferruginous soil, F plant inferruginous soil, CA Caricapapaya, VA Vernoniaamygdalina, MO Moringaoleifera, AZ Azadiractaindica ZO Hibiscus sabdariffa

Table 4 Mean number of days to panicle emergence

\begin{tabular}{llll}
\hline Treatment & \multicolumn{2}{l}{ Period (days) } & \\
\cline { 2 - 4 } & $N$ & $F$ & N value \\
\hline AZ5\% & 0 & 119 & 0.012 \\
CA5\% & 89 & 94 & 0.009 \\
ZO5\% & 89 & 101 & 0.038 \\
VA5\% & 87 & 98 & 0.218 \\
MO5\% & 87 & 93 & 0.043 \\
AZ15\% & 90 & 97 & 0.331 \\
CA15\% & 90 & 95 & $<0.001$ \\
ZO15\% & 89 & 97 & 0.735 \\
VA15\% & 90 & 93 & 0.835 \\
MO15\% & 87 & 89 & 0.004 \\
AZ30\% & 90 & 96 & $<0.001$ \\
CA30\% & 89 & 103 & $<0.001$ \\
ZO30\% & 87 & 102 & $<0.001$ \\
VA30\% & 87 & 94 & 0.629 \\
MO30\% & 92 & 95 & $<0.001$ \\
Control & 92 & 99 & \\
\hline
\end{tabular}

chlorotic disposition to green-yellow especially in CA5\% (Fig. 4b). Generally also in VA5\%, there was a prominent foliar colour disposition (olive drab) (Fig. 4d). However, with MO15\% upon application of nanoparticles in the 5 weeks wherein the prominent colour was originally olive drab there was an improvement in the colour of the leaf to green. Throughout the experiment, no leaf showed the dark green coloured disposition. Figure 5a shows the foliar yield of the nano-intervened plant at 12 weeks after sowing in non-ferruginous soil. AZ15\%, CA30\% had a high foliar yield compared to the control. VA5\% had a low yield. It was observed generally that other nanointervened plant had high yield than the control.

Figure $5 \mathrm{~b}$ shows the foliar yield of a nano-intervened plant at 17 weeks after sowing in ferruginous soil. It was observed that the foliar yields were generally low compared to the control, although AZ15\% and Ca30\% had significant growth. Correspondence analysis was conducted to show the association between treatment and some selected growth and yield parameters (Additional file 1: Fig. 3). The result showed a close association between $\mathrm{MO} 15 \%$ and the number of grains. This perhaps may indicate the possibility for this particular treatment to have great influence in the test plant. $\mathrm{ZO} 30 \%$ was found to be closely associated with the number of roots, plant height, root weight an indication that perhaps this particular treatment may have an influence on the said parameters compared to the others. Additional file 1: Fig. 4 shows a dendrogram from cluster analysis using Ward's method to present the association between the treatments in the study. The result showed that AZ5\% was a standalone and as such exerted a completely different influence compared to the others. The control was closely associated with $\mathrm{MO} 15 \%$ an indication that perhaps it may have entirely influenced the treatment the way others did and so may have a relatively similar effect as though there was no application of nanoparticles. CA5\% was also more associated with ZO15\%. Finally, a bivariate correlation of growth and yield parameters under the influence of applied nanoparticles showed a significant relationship between plant height and shelling per cent $(r=0.509, p<0.05)$ (Additional file 1: Table 4). Similarly, grain weight correlated significantly bivariately with shelling per cent $(r=0.706, p<0.01)$. Root weight was also bivariate positively with the number of leaves $(r=0.626, p=<0.1)$.

\section{Discussion}

The growth characteristics and yield performance of rice after exposure to biosynthesized nanoparticles in ferruginous soil and non-ferruginous soils have been assessed. Ferrugenicity is defined most especially the iron and aluminium content of the soil (Saheed and Ikhajiagbe 2020; 
Table 5 The effects of nanoparticles on the yield of rice plants at 12 weeks after sowing (8 weeks after application of nanoparticles) in non-ferruginous soil

\begin{tabular}{|c|c|c|c|c|c|c|}
\hline Treatment & $\begin{array}{l}\text { Wt. of spikelets/ } \\
\text { plant. (g) }\end{array}$ & $\begin{array}{l}\text { Wt. of rice grain/ } \\
\text { plant (g) }\end{array}$ & No. of grains/plant & $\begin{array}{l}\text { Length of rice } \\
\text { grain }(\mathrm{cm})\end{array}$ & Diameter of grain & Shelling (\%) \\
\hline AZ5\% & 0 & 0 & 0 & 0 & 0 & 0 \\
\hline CA5\% & 0.823 & 0.674 & 76 & 1.6 & 0.5 & 81.92 \\
\hline ZO5\% & 1.14 & 0.828 & 103 & 1.5 & 0.5 & 73.61 \\
\hline VA5\% & 2.691 & 2.281 & 155 & 1.5 & 0.4 & 82.64 \\
\hline MO5\% & 1.034 & 0.633 & 115 & 1.4 & 0.4 & 61.76 \\
\hline AZ15\% & 1.715 & 1.418 & 142 & 1.6 & 0.5 & 83.48 \\
\hline CA15\% & 1.379 & 1.08 & 133 & 1.4 & 0.4 & 78.62 \\
\hline ZO15\% & 0.657 & 0.533 & 80 & 1.5 & 0.4 & 81.93 \\
\hline VA15\% & 1.694 & 1.454 & 145 & 1.4 & 0.5 & 83.83 \\
\hline MO15\% & 1.382 & 0.978 & 162 & 1.5 & 0.4 & 72.95 \\
\hline AZ30\% & 1.967 & 1.707 & 130 & 1.4 & 0.4 & 84.22 \\
\hline CA30\% & 1.683 & 1.715 & 106 & 1.4 & 0.4 & 101.26 \\
\hline ZO30\% & 0.662 & 0.435 & 98 & 1.5 & 0.4 & 66.38 \\
\hline VA30\% & 0.752 & 0.504 & 125 & 1.4 & 0.5 & 67.32 \\
\hline MO30\% & 1.946 & 1.556 & 116 & 1.4 & 0.5 & 79.53 \\
\hline Control & 1.136 & 0.672 & 169 & 1.4 & 0.4 & 61.45 \\
\hline p value & 0.001 & $<0.001$ & $<0.001$ & $<0.001$ & $<0.001$ & $<0.001$ \\
\hline LSD(0.05) & 0.684 & 0.530 & 21 & 0.6 & 0.2 & 36.41 \\
\hline
\end{tabular}

Table 6 The effects of nanoparticles on the yield of rice plants at 17 weeks after sowing (12 weeks after application of nanoparticles) in ferruginous soil

\begin{tabular}{|c|c|c|c|c|c|}
\hline Treatment & No. of spikelets/plant & Wt. of panicle (g) & Root biomass (g) & $\begin{array}{l}\text { Wt. of Grain per plant } \\
\text { (g) }\end{array}$ & Shelling (\%) \\
\hline AZ5\% & 87 & 1.36 & 1.31 & 0.92 & 82.41 \\
\hline CA5\% & 113 & 0.9 & 1.82 & 0.66 & 78.24 \\
\hline ZO5\% & 56 & 2.92 & 1.33 & 2.41 & 81.23 \\
\hline VA15\% & 81 & 1.19 & 0.71 & 0.95 & 78.91 \\
\hline MO5\% & 47 & 0.43 & 2.4 & 0.29 & 70.43 \\
\hline AZ15\% & 167 & 5.84 & 1.05 & 4.66 & 81.24 \\
\hline CA15\% & 180 & 0.78 & 1.26 & 1.53 & 80.09 \\
\hline ZO15\% & 37 & 0.31 & 1.9 & 0.24 & 79.11 \\
\hline VA5\% & 133 & 0.8 & 0.88 & 0.59 & 81.21 \\
\hline MO15\% & 43 & 1.64 & 1.16 & 1.21 & 79.23 \\
\hline AZ30\% & 144 & 2.34 & 2.08 & 1.892 & 78.31 \\
\hline CA30\% & 310 & 2.58 & 1.2 & 0.97 & 84.53 \\
\hline ZO30\% & 69 & 1.57 & 3.75 & 1.04 & 71.34 \\
\hline VA30\% & 0 & 1.22 & 0.58 & 1.02 & 68.91 \\
\hline MO30\% & 155 & 0.71 & 1.17 & 1.1 & 73.10 \\
\hline Control & 0 & 1.41 & 1.37 & 1.97 & 68.13 \\
\hline$p$ value & 0.022 & $<0.001$ & 0.093 & $<0.001$ & 0.093 \\
\hline $\operatorname{LSD}(0.05)$ & 39 & 0.38 & 1.06 & 0.56 & 39.73 \\
\hline
\end{tabular}

Ikhajiagbe et al. 2021). The imbalance soil chemical constituent present physicochemical limitations to growth and development of plants especially non-native ones as reported by Urriago-Ospina et al. (2020). However, in their study, Urriago-Ospina (2020) opined that restoration and rehabilitation have proven to be successful in 
Table 7 Comparison of the yield performance of rice plants exposed to nanoparticles and sown in ferruginous and nonferruginous soils

\begin{tabular}{|c|c|c|c|c|c|}
\hline \multirow[t]{2}{*}{ Treatments } & \multicolumn{2}{|c|}{$\begin{array}{l}\text { Wt. of grain/plant } \\
\text { (g) }\end{array}$} & \multirow[t]{2}{*}{$p$ value } & \multicolumn{2}{|c|}{$\begin{array}{l}\text { Change in Wt. of } \\
\text { grain/plant (\%) }\end{array}$} \\
\hline & $\mathrm{N}$ & $\mathrm{F}$ & & $\mathrm{N}$ & $\mathrm{F}$ \\
\hline AZ5\% & 0 & 0.92 & $<0.001$ & -100 & -8 \\
\hline CA5\% & 0.674 & 0.66 & 0.887 & -32.6 & -34 \\
\hline ZO5\% & 0.828 & 2.41 & $<0.001$ & -17.2 & +141 \\
\hline VA5\% & 2.281 & 0.95 & $<0.001$ & +128.1 & -5 \\
\hline MO5\% & 0.633 & 0.29 & 0.125 & -36.7 & -71 \\
\hline AZ15\% & 1.418 & 4.66 & $<0.001$ & +41.8 & +366 \\
\hline CA15\% & 1.08 & 1.53 & 0.748 & +8 & +53 \\
\hline ZO15\% & 0.533 & 0.24 & 0.426 & -46.7 & -76 \\
\hline VA15\% & 1.454 & 0.59 & $<0.001$ & +45.4 & -41 \\
\hline MO15\% & 0.978 & 1.21 & 0.662 & -2.2 & +21 \\
\hline AZ30\% & 1.707 & 1.892 & 0.831 & +70.7 & +89 \\
\hline CA30\% & 1.715 & 0.97 & 0.003 & +71.5 & -3 \\
\hline ZO30\% & 0.435 & 1.04 & $<0.001$ & -56.5 & +4 \\
\hline VA30\% & 0.504 & 1.02 & $<0.001$ & -49.6 & +2 \\
\hline MO30\% & 1.556 & 1.1 & 0.173 & +55.6 & +10 \\
\hline Control & 0.672 & 1.62 & $<0.001$ & Nil & Nil \\
\hline
\end{tabular}

$N$ Plants sown in non-ferruginous soils ( $\mathrm{N}$ rice plants were harvested after 12 weeks), $F$ Plants sown in ferruginous soils (F-rice plants were harvested at 17 weeks after sowing) the improvement and management of ferruginous soils. On the other hand, nanoparticles have been reported to enhance the germination and growth of economic plants and in turn crop production (Aslani et al. 2014; Sadak 2019).

The growth patterns recorded in our investigation are in line with the findings of Hao et al. (2016) where they reported that exposure of rice to nanoparticles led stimulated root elongation and promoted shoot growth. Thuesombat et al. (2014) found plant growth decreases with increasing sizes and concentration of Ag-NPs. Gruyer et al. (2013) reported that Ag-NPs exhibit both positive and negative species-dependent effects on root elongation. They reported increased root length in barley, although was inhibited in lettuce. The effects of Ag-NPs on germination of eleven wetland plants species (Panicum virgatum, Juncus effuses, Scirpus cyperinus, Lolium multiflorum, Carex lurida, C. crinita, C. vulpinoidea, C. scoparia, Phytolaca americana, Eupatorium fistulosum, Lobelia cardinalis,) and establish Ag-NPs improved the germination rate of Eupatorium fistulosum only (Yin et al. 2012). Rezvani et al. (2012) established that Ag-NP induces root growth by blocking ethylene in Crocus sativus. Further, the observed effects might likely result from the morphological, physiological, biochemical and

Table 8 Occurrence of foliar necrosis during the study under experimental condition

\begin{tabular}{|c|c|c|c|c|c|}
\hline \multirow[t]{2}{*}{ Treatments } & \multirow[t]{2}{*}{ Pattern of necrosis } & \multicolumn{2}{|l|}{ Ferruginous } & \multicolumn{2}{|c|}{ Non-ferruginous } \\
\hline & & MNT (days) & FNP (\%) & MNT (days) & FNP (\%) \\
\hline AZ5\% & $\begin{array}{l}\text { Appeared first like patches and then spread all over the leaf until entire leaf became } \\
\text { necrotic }\end{array}$ & 3 & 45 & 5 & 100 \\
\hline CA5\% & Began at the tip of the leaf and spread downwards until entire leaf became necrotic & 4 & 35 & 8 & 29 \\
\hline $\mathrm{ZO5} \%$ & Began at the tip of the leaf and spread downwards until entire leaf became necrotic & 2 & 38 & 4 & 33 \\
\hline VA5\% & Began at the tip of the leaf and spread downwards until entire leaf became necrotic & 4 & 35 & 7 & 50 \\
\hline MO5\% & $\begin{array}{l}\text { Appeared first like patches and then spread all over the leaf until entire leaf became } \\
\text { necrotic }\end{array}$ & 6 & 40 & 11 & 28 \\
\hline AZ15\% & Began at the tip of the leaf and spread downwards until entire leaf became necrotic & 4 & 21 & 6 & 14 \\
\hline CA15\% & $\begin{array}{l}\text { Appeared first like patches located within the middle of the leaves, and then spread all } \\
\text { over the leaf until entire leaf became necrotic }\end{array}$ & 3 & 29 & 4 & 23 \\
\hline ZO15\% & Began at the tip of the leaf and spread downwards until entire leaf became necrotic & 3 & 33 & 5 & 27 \\
\hline VA15\% & Began at the tip of the leaf and spread downwards until entire leaf became necrotic & 3 & 23 & 5 & 18 \\
\hline MO15\% & $\begin{array}{l}\text { Appeared first like burnt patches as well as a couple of brown patches. Thereafter the } \\
\text { entire leaf became necrotic }\end{array}$ & 7 & 30 & 11 & 35 \\
\hline AZ30\% & $\begin{array}{l}\text { Appeared first like patches located within the middle of the leaves, and then spread all } \\
\text { over the leaf until entire leaf became necrotic }\end{array}$ & 5 & 40 & 8 & 17 \\
\hline CA30\% & Began at the tip of the leaf and spread downwards until entire leaf became necrotic & 8 & 38 & 12 & 25 \\
\hline ZO30\% & Began at the tip of the leaf and spread downwards until entire leaf became necrotic & 5 & 41 & 7 & 29 \\
\hline VA30\% & Began at the tip of the leaf and spread downwards until entire leaf became necrotic & 2 & 56 & 4 & 40 \\
\hline $\mathrm{MO} 30 \%$ & Began at the tip of the leaf and spread downwards until entire leaf became necrotic & 3 & 22 & 6 & 13 \\
\hline Control & Began at the tip of the leaf and spread downwards until entire leaf became necrotic & 4 & 34 & 6 & 20 \\
\hline p value & Not applicable & 0.169 & 0.512 & $<0.001$ & $<0.001$ \\
\hline
\end{tabular}


genotoxic interaction between the plants, nanomaterial and environmental conditions (Nair 2016).

Yield promotion and disease prevention have previously been reported from exposing rice to nanoparticles (Elamawi et al. 2020). The most effective treatment was AZ15\% and CA30\% in non-ferruginous soils. Increase in yield by the application of nanoparticles has been suggested earlier by several authors. Sharon et al. (2010) reported that silver is an excellent growth simulator. Najafi and Jamei (2014); Razzaq et al. (2016) and Sadak (2019) had similar results of improving the role of Ag-NP treatments. This increase in yield and yield components possibly is attributed to the increases in photosynthetic pigments, growth parameters, and IAA of treated rice plants. These yield performance may be linked to higher physiological efficiency for water use, phosphorus absorption and retention, photosynthetic rate, and biomass accumulation (Miranda-Villagomez et al. 2019). Spraying the rice plant (Fig. 5a) with Ag NPs showed a differential increase in the yield components of the rice plants.

According to data from Krishnaraj et al. (2012) and Monica and Cremonini (2009), only a few numbers of studies on Ag-NPs have conducted on plants. NPs have been known to have both positive and negative effects on plant growth and development but little is known about the effects on NPs on plant phytochemicals. Recently, Krishnaraj et al. (2012) examined the effects of biologically synthesized Ag-NPs on hydroponically grown Bacopa monnieri growth metabolism, where they observed that biosynthesized Ag-NPs demonstrated a significant effect on seed germination and induced the synthesis of carbohydrate, protein and decreased in the total antioxidant activities. Furthermore, biologically synthesized Ag-NPs improved germination of seeds and the growth of Boswellia ovaliofoliolata trees (Savithramma et al. 2012). Previous works have suggested that Ag-NPs increased leaf area, shoot and root length (plants growth parameters) and chlorophyll, antioxidant enzymes, carbohydrate and protein contents (biochemical attributes) of Brassica juncea, common bean and corn (Salama 2012; Sharma et al. 2012).

\section{Conclusion}

This study has revealed the effects of Ag-NP on Oryza sativa var. nerica. The different treatments showed closed association in some selected growth and yield parameters but most important was the significant increase in yield (AZ15\% and CA30\%) and vigour in non-ferruginous soils. The outcome of this present study may be useful in finding the potential of nanoparticles in crop improvement and other agricultural applications.

\begin{abstract}
Abbreviations
CA: Carica papaya; VA: Vernonia amygdalina; MO: Moringa oleiofera; AZ: Azadiracta indica; ZO: Hibiscus sabdariffa; IAA: Indole-3-Acetic Acid; F: Ferruginous soil; N: Non ferruginous soil; Wt: Weight; ml: Millilitres; mm: Millimetres; No.: Number; N-rice: Nerica rice (Oryza sativa var. nerica) meq/100 g; NPs: Nanoparticles; nm: Nanometer; pH: Hydroxyl ion (hydrogen potential); UV-VIS: Ultraviolet-visible; Ag-NPs: Silver nanoparticles; Fe: Iron; FAO: Food and Agriculture Organization; USAID: United States Agency for International Development; $\mu \mathrm{s} / \mathrm{cm}$ : Microsiemens per centimetre; \%: Percentage; mg/kg: Milligram per kilogram; cm: Centimetres; LSD: Least Significant Difference.
\end{abstract}

\section{Supplementary Information}

The online version contains supplementary material available at https://doi. org/10.1186/s42269-021-00508-y.

Additional file 1. Table 1. Physical and chemical properties of experimental soils.Table 2. Similarity index between treatments in the nonferruginous soil based on all the plant parameters assessed in the study. Table 3. Similarity index between treatments in the ferruginous soil based on the all the plant parameters assessed in the study. Fig. 3. Correspondence analyses showing the association between treatments and selected growth and yield parameters. Fig. 4. Dendrogram of cluster analysis by Ward's Method showing the association between treatments in the study. Table 4. Bivariate correlation of growth and yield parameters under the influence of biosynthesized nanoparticles.

\section{Acknowledgement}

The researchers wish to thank the Management of Raymos Guanah Farms Limited, Delta State, Nigeria, for providing the viable seeds of the rice variety used in the study.

\section{Authors' contributions}

$\mathrm{BI}$ conceived the project idea and developed the research strategy with $\mathrm{Fl}$. FI and $\mathrm{BI}$ collected the data while $\mathrm{MO}$ performed the statistical analysis. Bl, Fl and $\mathrm{MO}$ contributed to writing the manuscript. All authors read and approved the final version of the manuscript.

Funding

Not applicable.

Availability of data and materials

Not applicable.

Declaration

Ethics approval and consent to participate

Not applicable.

Consent to publish

Not applicable.

Competing interest

The authors declare that they have no competing interests.

\section{Author details}

${ }^{1}$ Department of Plant Biology and Biotechnology, Faculty of Life Sciences, University of Benin, PMB 1154, Benin, Edo, Nigeria. ${ }^{2}$ Department of Microbiology, College of Natural and Applied Sciences, Wellspring University, Benin, Nigeria. ${ }^{3}$ School of Biosciences and Veterinary Medicine, University of Camerino Center for Floristic Research of the Apennine, Gran Sasso and Monti Della Laga National Park, San Colombo, 67021 Barisciano, L'Aquila, Italy. 
Received: 4 December 2020 Accepted: 22 February 2021

Published online: 18 March 2021

\section{References}

Akande T (2003) The rice sector in Nigeria, United Nation Crop Project (UNCP). Country Agricultural Project on Trade Liberalization in Agricultural Sector and the Environment, Geneva, Switzerland. Afr Crop Sci J 15(4):223-235

Anandalakshmi K, Venugobal J (2017) Green synthesis and characterization of silver nanoparticles using Vitex negundo (Karu Nochchi) leaf extract and its antibacterial activity. J Med Chem 7:218-225

APHA (2008) Standard methods for the examination of water and wastewater. American Public Health Association, Washington

Aslani F, Bagheri S, Julkapli NM, Juraimi AS, Hashemi FSG, Baghdadi A (2014) Effects of engineered nanomaterials on plant growth: an overview. Sci World J Article ID 641759

Bivbere G (2018) Kebbi State earned N150bn from rice sales in 2017-GOV. https://www.vanguardngr.com/2018/08/kebbi-state-earned-n150b n-from-rice-sales-in-2017-gov/. Accessed 10 Mar 2019

Elamawi RM, Tahoon AM, Elsharnoby DE, El-Shafey RA (2020) Bio-production of silica nanoparticles from rice husk and their impact on rice bakanae disease and grain yield. Arch Phytopathol Plant Prot. https://doi. org/10.1080/03235408.2020.1750824

FAO (2001) Towards improving the operational effectiveness of the Marrakesh decision on the possible negative effects of the reform programme on least developed and net-food importing developing countries. Discussion Paper No. 2. 21 March 2001, FAO Geneva Round Table on Selected Agricultural Trade Policy Issues, Geneva

FAO (2003) A regional rice strategy for sustainable food security in Asia and the pacific. FAO Regional Office for Asia and the Pacific, Bangkok

Gruyer N, Dorais M, Bastien C, Dassylva N, Triffault-Bouchet G (2013) Interaction between sliver nanoparticles and plant growth. In: International symposium on new technologies for environment control, energy-saving and crop production in greenhouse and plant factory — greensys, Jeju, Korea, 6-11 Oct 2013

Hao Y, Zhang Z, Rui Y, Ren J, Hou T, Wu S, Rui M, Jiang F, Liu L (2016) Effects of different nanoparticles on seed germination and seedling growth in rice. In: Proceedings of the 2 nd annual international conference on advance material engineering. Atlantis Press, Netherland

Ikhajiagbe B, Ogwu MC (2020) Hazard quotient, microbial diversity and plant composition of spent crude oil polluted-soil. Beni-Suef Univ J Basic Appl Sci. https://doi.org/10.1186/s43088-020-00052-0

Ikhajiagbe B, Ogwu MC, Fawehinmi FO, Adekunle IJ (2021) Comparative growth responses of Amaranthus [L.] species in humus and ferruginous ultisols using plant growth promoting Rhizobacteria (Pseudomonas species). S Afr J Bot 137:10-18. https://doi.org/10.1016/j.sajb.2020.09.029

Khodakovskaya MV, de Silva K, Biris AS, Dervishi E, Villagarcia H (2012) Carbon nanotubes induce growth enhancement of tobacco cells. ACS Nano 6(3):2128-2135

Krishnaraj C, Jagan EG, Ramachandran R, Abirami SM, Mohan N, Kalaichelvan PT (2012) Effect of biologically synthesized silver nanoparticles on Bacopa monnieri (Linn.) Wettst. Plant growth metabolism. Process Biochem 47(4):651-658

Miranda-Villagomez E, Trejo-Tellez LI, Gomez-Merino FG, Sandoval-Villa M, Sanchez-Garcia P, Aguilar-Mendez MA (2019) Nanophosphorus fertilizer stimulates growth and photosynthetic activity and improves P status in rice. J Nanomater. https://doi.org/10.1155/2019/5368027

Monica RC, Cremonini R (2009) Nanoparticles and higher plants. Caryologia 62(2):161-165

Moran R (1982) Formulae for determination of chlorophyll pigments extracted with N,N-dimethylformamide. Plant Physiol 69:1376-1381

Nair R (2016) Effects of nanoparticles on plant growth and development. In: Kole C, Kumar DS, Khodakovskaya MV (eds) Plant nanotechnology. Springer, Berlin, pp 95-118

Najafi S, Jamei R (2014) Effect of silver nanoparticles and $\mathrm{Pb}\left(\mathrm{NO}_{3}\right)_{2}$ on the yield and chemical composition of mung bean (Vigna radiata). I Stress Physiol Biochem 10(2014):316-325

Ngo QB, Dao TH, Nguyen HC, Tran XT, Nguyen TV, Khuu TD, Huynh TH (2014) Effects of nanocrystalline powders ( $\mathrm{Fe}, \mathrm{Co}$ and $\mathrm{Cu}$ ) on the germination, growth, crop yield and product quality of soybean (Vietnamese species DT-51). Adv Nat Sci Nanosci Nanotechnol 44(19):7315-7320

Nwite JC, Essien BA, Essien JB, Eke BA, Keke Cl, Igwe CA, Wakatsuki T (2010) The contribution of different sources of ash on the soil improvement and rice yield in a sawah rice farming in southeastern Nigeria. In: Proceedings of the 44th annual conference of the Agricultural Society of Nigeria held at LAUTECH, Ogbomosho, Oyo State, pp 988-992

Ogwu MC (2019a) Lifelong consumption of plant-based GM foods: is it safe? In: Papadopoulou P, Misseyanni A, Marouli C (eds) Environmental exposures and human health challenges. IGI Global, Pennsylvania. https:// doi.org/10.4018/978-1-5225-7635-8.ch008

Ogwu MC (2019b) Towards sustainable development in Africa: the challenge of urbanization and climate change adaptation. In: Cobbinah PB, Addaney M (eds) The geography of climate change adaptation in Urban Africa. Springer, Berlin. https://doi.org/10.1007/978-3-030-04873 $-0 \_2$

Ogwu MC, Osawaru ME, Obayuwana KO (2016) Diversity and abundance of tree species in the University of Benin, Benin City, Nigeria. Appl Trop Agric 21(3):46-54

Osawaru ME, Ogwu MC (2013) Collecting West African Okra (Abelmoschus caillei (A. Chev.) Stevels) germplasm from traditional agriculture in parts of Southwestern Nigeria. The Bioscientist 1(2):171-181

Osawaru ME, Ogwu MC (2020) Survey of plant and plant products in local markets within Benin City and environs. In: Filho LW, Ogugu N, Ayal D, Adelake L, da Silva I (eds) African handbook of climate change adaptation. Springer, Berlin. https://doi.org/10.1007/978-3-030-42091-8_159-1

Osawaru ME, Ogwu MC, Braimah L (2013a) Growth responses of two cultivated Okra species (Abelmoschus caillei (A. Chev.) Stevels and Abelmoschus esculentus (Linn.) Moench) in crude oil contaminated soil. Nigerian J Basic Appl Sci 21(3):215-226

Osawaru ME, Ogwu MC, Chime AO (2013b) Assessment of growth performance of two Okra species (Abelmoschus esculentus [L.] Moench and Abelmoschus caillei [A. Chev.] Stevels) exposed to crude oil contaminated soil. Nigerian J Biotechnol 26:11-20

Osawaru ME, Ogwu MC, Chime AO, Ebosa AB (2014) Weed flora of University of Benin in terms of diversity and richness using two ecological models. Sci Afr 13(2):102-120

Razzaq A, Ammara R, Jhanzab HM, Mahmood T, Hafeez A, Hussain S (2016) A novel nanomaterial to enhance growth and yield of wheat. J Nanosci Technol 2(1):55-58

Rezvani N, Sorooshzadeh A, Farhadi N (2012) Effect of nano-silver on growth of saffron in flooding stress. World Acad Sci Eng Technol 1:517-522

Saheed M, Ikhajiagbe B (2020) Assessment of physico-chemical properties of ferruginous utisol in Benin City, Edo State: possible impact on plant distribution. Studia Universitatis Vasile Goldis Arad Seria Stiintele Vietii 30(2):88-95

Sadak MS (2019) Physiological role of trehalose on enhancing salinity tolerance of wheat plant. Bull Natl Res Acad 43, Article number 53

Saka JO, Lawal BO (2009) Determinants of adoption and productivity of improved rice varieties in southwestern Nigeria. Afr J Biotechnol 8(19):4923-4932

Salama HMH (2012) Effects of silver nanoparticles in some crop plants, common bean (Phaseolus vulgaris L.) and corn (Zea mays L.). Int Res J Biotechnol 3(10):190-197

Savithramma N, Ankanna S, Bhumi G (2012) Effect of nanoparticles on seed germination and seedling growth of Boswellia ovalifoliolata an endemic and endangered medicinal tree taxon. Nano Vis 2:61-68

Sharma P, Bhatt D, Zaidi MG, Saradhi PP, Khanna PK, Arora S (2012) Silver nanoparticle mediated enhancement in growth and antioxidant status of Brassica juncea. Appl Biochem Biotechnol 167:2225-2233

Sharon M, Choudhary AK, Kumar R (2010) Nanotechnology in agricultural diseases and food safety. J Phytol 2(4):83-92

Thuesombat P, Hannongbua S, Akasit S, Chadchawan S (2014) Effect of silver nanoparticles on rice (Oryza sativa L. Cv. KDML 105) seed germination and seedling growth. Ecotoxicol Environ Saf 104:302-309. https ://doi.org/10.1016/j.ecoenv.2014.03.022

Urriago-Ospina LM, Jardim CM, Rivera-Fernández G, Kozovits AR, Leite MGP, Messias MCTB (2020) Traditional ecological knowledge in a ferruginous ecosystem management: lessons for diversifying land use. Environ Dev Sustain. https://doi.org/10.1007/s10668-020-00665-6 
USDA (2010) Soil survey field and laboratory methods manual. Soil Survey Investigations Report No. 51, Version 1.0. In: Burt R (ed) U.S. Department of Agriculture, Natural Resources Conservation Service, Lincoln, Nebraska Yin L, Colman BP, McGill BM, Wright JP, Bernhardt ES (2012) Effects of silver nanoparticle exposure on germination and early growth of eleven wetland plants. PLOS ONE 7:1-7

\section{Publisher's Note}

Springer Nature remains neutral with regard to jurisdictional claims in published maps and institutional affiliations.
Submit your manuscript to a SpringerOpen ${ }^{\ominus}$ journal and benefit from:

- Convenient online submission

- Rigorous peer review

- Open access: articles freely available online

- High visibility within the field

- Retaining the copyright to your article

Submit your next manuscript at $\boldsymbol{\nabla}$ springeropen.com 